flushes from behind, the rate goes up to fifteen days. There is a very great difference in time and rate between Green and Red Nile. The rise is $45 \mathrm{ft}$. at Aswân, 38 at Thebes, and 25 at Cairo.

From the data obtained at the gauges named which have been kindly forwarded to me by Mr. Garstin, the U.S. of State of the Public Works Department of Egypt, I have ascertained that the average time taken by the flood to travel now between Thebes and Memphis is about nine days. Although the river bed is now higher than formerly, the land around Thebes, according to Budge, having been raised about nine feet in the last 1700 years, still the same elevation has taken place at Memphis, so that no difference in the velocity of the stream would be produced by this cause.

The great difficulty experienced in understanding the statements generally made concerning the Nile-rise arises from the fact that the maximum flood is as a rule registered in Cairo upwards of 40 days after the maximum of Aswân.

For the following account of how this is brought about I am indebted to the kindness of Col. Ross, R.E. :-

"The behaviour of the flood at the Aswân gauge is as follows: Between August 20 and 30 a good average gauge of 16 cubits is often reached, and between August 27 and September 3 there is often a drop of about 30 centimetres. The August rise is supposed to be mostly due to the Blue Nile and Atbara River. Between September $I$ and 8 the irrigation officers generally look for a maximum flood-gauge of the year at Aswân. This is supposed to be the first flush of the White Nile. In the middle of September there are generally two small flushes, but the last twenty days of September are generally distinctly lower than that of the first week. The final flush of the Nile is seldom later than the 2 rst to 25 th September.

"All this water does not merely go down the Nile; it floods the different basins. The opening of these basins begins from the south to the north. This operation is generally performed between the 2 th September and the 22nd October. The great Central Egypt basins are not connected with the Nile for purposes of discharge into the river between Asyût and near Wasta, or a distance of $395-90$ kilometres $=305$ kil.

"The country in the middle or Central Egypt is broad, and thus there is an enormous quantity of water poured out of these basins into the lower reaches of the river about the 2oth October, which seriously raises the Nile at Cairo, and in a good average year will bring the Cairo gauge (at Rodah) up to the maximum of the year on or about October 22, and hence it is that the guide books say the Nile is at its highest in the end of Uctober.

"A gauge of $16 \frac{1}{2}$ cubits at Aswân while the basins are being filled does not give more than 21 cubits at Rodah (Cairo), but as the basins with a $16 \frac{1}{2}$ gauge will fill by the Ioth September, it follows that a $16 \frac{1}{2}$ to 16 cubit gauge at Aswân will not give a constant Cairo gauge, as the great mass of water passes by the basins and reaches Cairo. Hence we have frequently the paradox of a steady or falling gauge at Aswân showing a steady rise at Cairo.

"It the gauge at Aswân keeps above 16 cubits to near the end of September, the basin-emptying is much retarded, as the emptying at each successive basin fills the Nile above the 16 cubit level; hence the lower halves of the chains of basins do not flow off, and thus when the great Middle Egypt basins are discharged, they do not raise the Nile so much as they do when the last half of September Nile is below 16 at Aswân.

"In years like $188 \%$ and 1892 , which differ from each other only in date of maximum gauge at Aswân, the river, having filled the basins in 15 to 20 days instead of in 25 to 30 days, comes down to Cairo in so largely increased a volume that a really dangerous gauge of 25 cubits at Cairo is maintained for over a fortnight (the average October gauge in Cairo is about 23 cubits), and from September Io to October 25 the river remains from 24 cubits to $25^{\frac{1}{2}}$ cubits, and the Middle Egypt basins discharge so slowly that the opening day is hardly traceable on the Cairo gauge.

"In the I 878 flood, which was the most disastrous flood possible, the river rose in the most abnormal fashion, and on October 3 attained 18 cubits at Aswân. This breached the Delta, and in addition so delayed the Upper Egypt basins emptying from the reason before given that the wheat was sown too late, and got badly scorched by the hot winds of March and April."

J. NORMAN LOCKYER.

\section{THE LANDSLIP AT SANDGATE.}

THE causes of landslips are in general so well known and the localities which are liable to them so clearly defined on geological principles that when on Monday, March 6, the public were startled by the news of a landslip at Sandgate, the probability would be that geologists who knew the district would be by no means surprised, more particularly as the locality of the catastrophe is in the midst of a typical section shown in many of the textbooks, and the town itself gives its name to a subdivision of the Cretaceous rocks.

The event, however, does not appear to have been expected, and since it has happened conjectures as to its cause have been numerous; but the true explanation has been wanting.

The series of rocks which, in descending order, form the country about Sandgate are the Folkestone beds, the Sandgate beds, the Hythe beds, and the Atherfield clay. Amongst these it is natural to look in the first instance for the presence of clays, as the probable origin of a landslip, though very loose sands have also been known to give way. The Folkestone beds are for the most part sand and they are bound together by bands of grit. Moreover, they are above the affected area. The Hythe beds are likewise characterised by bands of hard limestone, separated by calcareous sands. There are left the Atherfield clay, whose nature is indicated by its name, and the Sandgate beds.

The most recent description of these is that of W. Topley, F.R.S., in the Comptes Rendus of the Congrès Géologique International, I 888 , in which they are briefly characterised (p. 257) as "Argiles vertes et sables." The same writer's description of them in 1883 (quoted also by H. B. Woodward in 1887 ) is somewhat different, but in his "Geology of the Weald," I 875 , they are said to consist of dark clayey sand and clay, the total thickness being given as $80 \mathrm{ft}$. In his more detailed description, however, $\mathrm{Mr}$. F. G. H. Price divides these $80 \mathrm{ft}$. into four parts, the lowest $20 \mathrm{ft}$. being all " clayey beds" (Proc. Geol. Assoc., vol. iv. p. 554). In a still earlier account by Prof. Morris (l.c. vol. ii. p. 4I) we have the following interesting statement:"The dark-greenish sub-argillaceous sands, known as the Sandgate beds, rise on the shore at a short distance west of Folkestone. The low undercliff which skirts the shore from Folkestone nearly to Hythe owes its origin to the presence of these beds, which from their retention of water and slight coherency of structure have caused the frequent subsidence of the beds above."

It would appear, then, that there are two possible sources of the slipping-the Atherfield clay and the clayey bands of the Sandgate beds, and thus much was indicated at once by Mr. F. W. Rudler (Daily Graphic, March 8).

On a personal examination of the area the whole history of the subsidence becomes clear enough. At

The modern Egyptians still hold to the old months for irrigation. 7 Tuba = January 15 is commencement of wheat irrigation; 30 Misra is the last safe date for sowing maize in the Delta ; Ist ' $T$ ut is the date of regulating the bridges=September 8 in Upper Egypt.

NO. I 220 , VOL. 47] 
Sandgate itself neither the Atherfield clay nor the Sand. gate beds are well exposed, but on the seashore between there and Folkestone we meet with the white-weathering massive limestone of the Hythe beds at Mill Point, and to the west of it. They are here dipping east at a moderate angle, and if this dip is continued, as the beds rise to the west, there would be room for the 60 feet of them which are seen at Hythe, between their probable outcrop in the lower part of the Enbrook Valley and lowwater mark, opposite its debouchure. It must be here, if anywhere, that the recorded appearance of Atherfield clay occurs for the state of things above described must here be terminated by a fault, as will be presently explained, and nowhere else along the coast till Sandgate is entirely passed can this clay occur within 40 yards seaward of low-water. On the east side of Enbrook, however, there is no landslip, and the actual landslip is thus shown to have nothing to do with the Atherfield clay.

Above the strong bands of Hythe limestone, however, west of Mill Point, are seen about 20 feet of soft, crumbling clay, occupying the base of the low cliff and becoming sandier above, as described by Mr. Price, and it is easily seen that the bottom of the Enbrook Valley is excavated in clay. The same clay is admirably seen on the other side of Sandgate, in the first cutting beyond Hythe Station on the branch line from Sandling Junction, so spring, which may indicate the line of another fault ; or it may be that all this is only a surface slip; but, in any case, Folkestone beds occupy the actual surface.

The strike faults thus indicated are only what we might expect if the strata broke, as they so often do, during their upheaval. It is plain that such faults will rather complicate the surface exposure of the clayey rocks which overlie the Hythe limestone. Now, if we allow some Ioo feet for the Sandgate beds, so as to include in the title all that portion of the series above the clay band at the base, which is not strengthened by the occurrence of indurated bands, and draw, from the purely geological considerations detailed above, the boundary of their surface exposure, which will not be an entirely simple one, it exactly coincides with the boundary of the disturbed area. Thus the upper boundary commences just beyond the town on the west, and runs very nearly along the line of the most westerly fault, till the latter has Folkestone beds on both sides of it; it then changes direction, and runs parallel to the outcrop of the Hythe beds on the foreshore, sloping down to a point above West Lawn, that is, to the probable position of the second fault; it is then thrown back along the probable line of that fault. It then again changes its direction and runs at first parallel to the second outcrop of the Hythe limestone, afterwards sloping down rapidly to the shore, so as to follow what

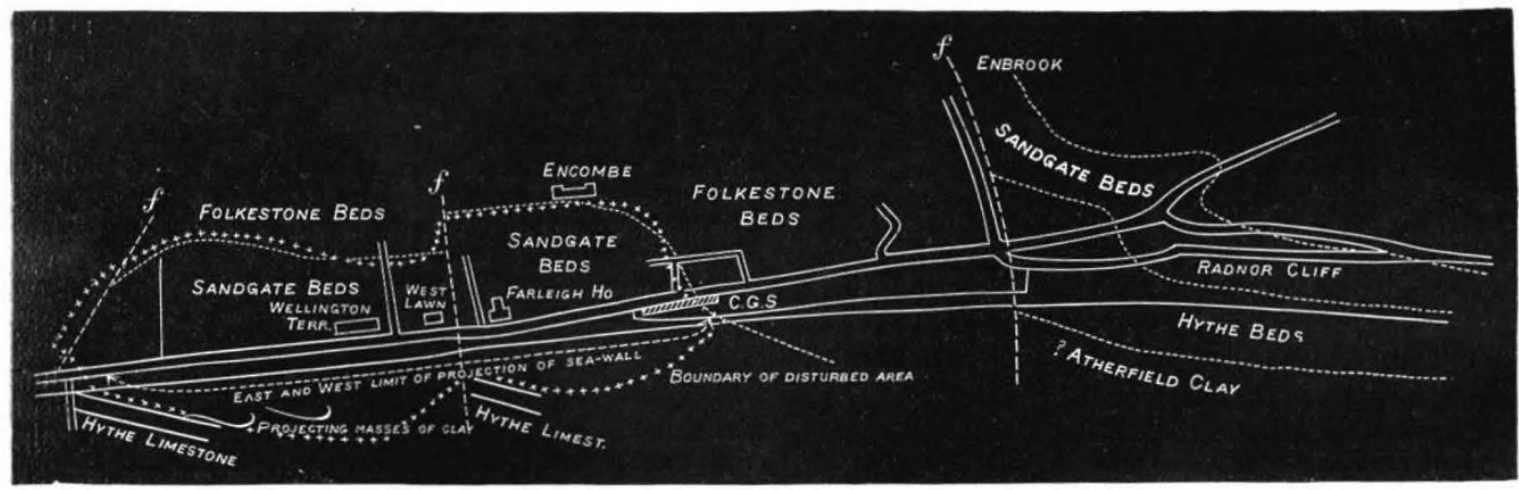

that though it is not now well exposed in Sandgate itself, we may be sure that it forms a continuous band immediately above the Hythe limestone.

Now, continuing to examine the coast below Sandgate on the west side of Enbrook we find an outcrop of Hythe limestone nearly opposite Farleigh House. Here also it has a dip towards the east; but it has also an abnormally high dip-perhaps $10^{\circ}$-inshore; such a dip in itself indicates a dislocation in the neighbourhood, but independently of this, the position of this band at the same level as that at Mill Point, while both bands dip, proves that there is a fault between the two, probably along the Enbrook Valley, with a downthrow on the west. This brings down the clay band at the base of the Sandgate beds to the sea level immediately to the east of the limestone above mentioned, and further on, to the east of the coastguard station, the sandy beds of the Folkestone series, which may, however, have slipped.

Going further west, we find the same band of Hythe limestone exposed on the sloping shore, having a similar easterly dip; but not so great an inshore dip, which, unless this were a lower band of Hythe limestone (which other observations negative), proves a second fault between these two, with a downthrow also to the west, but of smaller amount. Further west again, and just beyond the town, the sandy Folkestone beds are found at a lower level than they should be if the stratification were regular, and in the slight valley intervening there is a would be probably the line of outcrop of the first hard band in the possibly slipped mass of the Folkestone beds. The conclusion from this seems inevitable. The whole disturbance is due to a motion of soft Sandgate beds where they are unprotected by the overlying hard bands of the Folkestone beds.

The nature of the motion can be determined by an examination of its upper, and particularly of its lower limit. The greatest amount of visible disturbance has taken place along the upper limit ; here the ground is seen to have slipped downwards and forwards. This might be caused by the collapse of an underground hollow if such a thing were possible, but the loose sandy and clayey nature of the rocks would not admit of such a hollow being formed, and the thick clay band at the base would effectually shield the Hythe limestones from chemical erosion. The lower limit, however, shows very plainly that the motion has been a simple slip in a south-east or east-south-east direction. In the first place the westerly band of Hythe limestone on the foreshore which abuts against a concrete groin is absolutely unmoved, and the sea-wall above is quite intact (which is a second proofif, after what has been said above, any further proof were needed, that the Atherfield clay has nothing whatever to do with the matter). In the second place, immediately to the east of this outcrop, the sea-wall has bulged forward by about three feet, as shown by the next, wooden, groin, and near low-water mark the overlying clay is seen

No. 1220 , vOT. 47 ] 
to be bulged up, so as to form a mound on the foreshore, which is being rapidly destroyed by the sea ; while further east, opposite the end of Wellington Terrace, the overlying more sandy clays are also seen bulged up. Along the main road also, in front of West Lawn, on the western side of the supposed fault, the surface has been squeezed up. On the eastern side of this fault, further cracks, indicating a forward motion, are seen at the entrance to Encombe grounds; and, finally, the Coast Guard houses and the wall in front bulge forward at least three feet, and probably more, and the two sides of the street opposite have been squeezed together.

Thus the whole disturbance has been caused by the slipping downwards of the overlying soft beds over the inclined plane formed by the basement band of clay which rests on the Hythe limestone as a firm foundation, the direction of motion having been somewhat modified by the resisting mass of rock which lies to the east, and by the natural tendency of the sliding mass to take the shortest course to a lower level.

It is thus seen that the circumstances of the locality exactly fulfil the usual geological conditions for a landslip-i.e. a sloping bed of clay, which is liable to become slippery, and whose dip is towards the lower surface level where the overlying rocks find no support. Hence it may safely be said that any geologist, whose attention had been specially directed to the question, could have predicted that such an occurrence was extremely likely, sooner or later, to happen. There is, however, one necessary condition, which does not depend on the lie of the strata and the form of the ground, and that is that the clay should become slippery. This condition will probably account for the fact that in the area to the east of the Enbrook fault where all the other conditions are satisfied, i.e. in the neighbourhood of Radnor Cliff, no landslip has occurred. Clay is of course rendered slippery by the access of water. Now water will easily find its way through sandy strata, and there are sandy beds even in the lower portion till we come to the band of clay itself. As this is equally true in both localities the only difference can be in the amount of water.

Now there is a natural tendency for water to run down the dip slope of the strata, especially when there are hard bands as in the Folkestone beds, so that in this case most of the water will come from the west, and this source is cut off from the Radnor Cliff side by the Enbrook Valley, to the east of which there is little or no gathering ground; but to the west and north-west of the disturbed area there is a wide expanse of high ground, mostly rising Ioo feet above the level of the Sandgate beds, and the water which falls on this finds its easiest outlet into these beds. They are therefore exactly in a position to get waterlogged, and that they are so is shown by the numerous springs that may be seen along the upper limit of the disturbed area.

The above considerations show that this area always has been and always will be liable to landslips. The lie of the beds which produces this liability cannot be altered by human agency, but the liability may be reduced to a minimum by a suitable system of drainage, which shall prevent the access of so large a body of water to so dangerous an area.

In the meantime the inhabitants of Sandgate may congratulate themselves that the shoreward dip of the beds and fault which breaks their continuity have reduced the result of the slip to a minimum, and rendered possible the remarkable circumstance that, though it happened in an area covered with houses, not a single house has been actually thrown down-not a single life lost.

As to the immediate cause of the occurrence, it is perhaps scarcely necessary to look for it. The landslip must necessarily have occurred at some time or another, and the conditions must for a long time have been gradually accumulating, by the constant access of water and the wearing action of the sea. If, however, the free discharge of the water from the beds has been in any way interfered with-by the stoppage of wells, or the construction of imperforate sea-walls--this would doubtless tend to the acceleration of the catastrophe ; and an exceptionally wet season, like that we have recently experienced, might suffice to determine it. It would be scarcely necessary to add, except that the idea has been mentioned in the House, that the blowing up of the Benvenue and the Calypso could have absolutely nothing to do with it : in the first place, because the scene of the explosions was to the west of the disturbed area, and cut off from it by the massive Hythe beds, which are absolutely undisturbedto say nothing of the Atherfield clay at sea which must necessarily intervene; secondly, because such a cause could not require several months to operate; and, lastly, because a vibration would rather tend to cause such beds to settle than to slip.

J. F. BLAKE.

\section{NOTES.}

Prof. VIRchow will deliver the Croonian Lecture this afternoon, and in the evening he will be entertained at the public dinner which is to be given in his honour at the Hôtel Métropole. It may at the same time be noted that an important scientific work, in three volumes, has just been issued by the Berlin publisher, August Hirschwald, in memory of the celebration of Prof. Virchow's seventieth birthday. The work is entitled. "Internationale Beiträge zur Wissenschaftlichen Medicin," and among the contributors to it are Sir James Paget, Sir Joseph Lister, and other English writers.

A Movement has been started for the celebration of the hundredth anniversary of the birth of the illustrious Russian mathematician, Lobatcheffsky, who was described by the late Prof. Clifford as "the Copernicus of geometry." He was born on October 10, 1793. It is proposed that honour shall be done to his memory at the Imperial University of Kasan, with which he was for many years connected as a professor and as rector. The Physico-Mathematical Society of the University, which has taken the matter in hand, hopes to be able either to establish a prize with Lobatcheffsky's name for researches in mathematics, or to erect a bust of the great investigator in the University buildings. If the funds suffice, both of these things will be done. Subscriptions should be sent to the Physico-Mathematical Society, Kasan.

THE German Congress of Naturalists and Physicians, which was postponed last year on account of the outbreak of cholera, is to meet this year at Niirnberg.

Prof. W. C. Roberts-Austen, F.R.S., chemist and assayer to the Royal Mint, and Mr. Thomas Bryant, President of the Royal College of Surgeons, have been elected members of the Athenreum Club, under the provisions of the rule by which the Committee is empowered to elect annually nine persons "of distinguished eminence in science, literature, the arts, or for public services."

THE half-yearly general meeting of the Scottish Meteorological Society was held at Edinburgh on Monday, March I3. The council of the society submitted its report, and the following papers were read :-On the temperatures of Lochs Lochy and Ness as affected by the wind, by Dr. Murray; mean temperature of London from 1763 to 1892 , by Dr. Buchan; hygrometric researches at the Ben Nevis Observatories, by A. J. Herbertson.

WE understand that an enormous iron meteorite weighing nearly one ton ( 2044 lbs.) has just been received by Mr. J. R.

NO. I 220 , VOL. 47 ] 